Ann. Génét. Sél. anim., I976, 9 (3), 427-434.

\title{
SOME GENETIC ASPECTS IN TWO STRAINS OF CHICKEN AND THEIR CROSSES
}

\author{
M. F. AMER, H. AYOUB and E. A. AFIFI ( ${ }^{(1)}$ \\ Animal Production Department, Faculty of Agriculture, \\ Ain-Shams University \\ Cairo (Égypt)
}

\section{SUMMARY}

An experiment was carried out to study the ratios of female to male bady weight means and variances in Rhode Island Red (RIR) and Dandrawi (Dand.) strains as well as in their two possible crossbred combinations (RIR-Dand. and Dand-RIR). Heterosis percentages for female and male body weight at different ages up to 20 weeks of age were also calculated. Four successive hatches comprising I 439 chicks were obtained within one season at intervals of one week. Individuals of the two strains and their reciprocal crosses were given identical managemental conditions. Results could be summarized as follows.

Differences between the mean body weight of the two sexes in each RIR-Dand. and Dand.$R I R$ crosses was larger than that of any of the two parental strains, and this indicates the probability of the existence of homogametic heterosis (STONAKER, I963).

Ratios of female to male body weight variance in chicken were not in accordance with the corresponding ratios of body weight means. These ratios varied for the four breeding groups of the study and this may be due to specific biological causes which are affected by heredity.

Heterotic effects on body weight of RIR-Dand. and Dand.-RIR crosses up to 20 weeks of age were clearly observed but with greater degree in Dand.-RIR crossbred group.

Heterosis percentages of body weight of the crosses obtained were always higher in males (the homogametic sex) than in females (the heterogametic sex).

No consistent trend was detected for the effect of age of the chicken on heterotic effects in their body weight up to 20 weeks.

\section{INTRODUCTION}

During the last twenty years, the subject of using linecrossing and crossbreeding attracted the attention of poultry breeders. STONAKER ( 1962 et I963) reported greater ratios of hybrid to inbred weights in the homogametic sex than in the heterogametic sex and suggested the existence of a phenomenon known as " homogametic hete-

(1) Faculty of Agricultural Sciences, at Moshtohor, Helwan University. 
rosis ". Result of some other investigators showed different degrees of heterosis in males and females, but did not consistently support the previous hypothesis (KIDWELL, I963 and KIDWELL, and NASH, 1964). The latter investigators recommended additional studies to determine the nature and extent of homogametic heterosis. STONAKER (1963) indicated that the greater the heterosis in the homogametic sex, the greater the sex difference is expected in turkeys and broiler chickens. MÉRAT and AyouB (1973) stated that the previous phenomenon might go further than the ratio of mean body weight of the two sexes to the ratio of body weight variance of females to that of males.

The present study was carried out to test the hypothesis of the existence of homogametic heterosis in body weight of Rhode Island Red and Dandarawi single crosses at different ages up to 20 weeks. The ratio of body weight variance of females to that of males and heterosis percentage were also studied with the aim to obtain further information to be used in a breeding program for improving broiler meat production.

\section{MATERIALS AND METHODS}

\section{Materials}

Rhode Island Red $(R I R)$ and Dandavawi (Dand.) strains were bred and mated to each other to produce two purebred groups and their two reciprocal crosses (RIR-Dand and Dand-RIR). The Dand. strain originated in Upper Egypt and has been handled for improvement, 25 years before the start of this experiment, in the Poultry Farm of the Ministry of Agriculture at Dokki. Data included were collected on I 439 chickens of four successive hatches taken at intervals of one week during one breeding season.

There are four sires per experimental group.

\section{Statistical analysis}

The ratio of body weight variance of females to that of males for the purebred and crossbred groups was tested according to the method which was mentioned by MÉRAT and AyouB (I973) for comparing groups two by two

$$
t=\frac{Z_{\mathrm{A}}^{1}-Z_{\mathrm{B}}^{1}-\left(\mathrm{M}_{\mathrm{A}}-\mathrm{M}_{\mathrm{B}}\right)}{\sqrt{\sigma_{\mathrm{A}}^{2}+\sigma_{\mathrm{B}}^{2}}}
$$

where :

$$
\begin{gathered}
Z_{\mathrm{A}}^{1}=1 / 2 \ln \left(\mathrm{F}_{\mathrm{A}}^{1}\right), \\
\mathrm{F}, \frac{\mathrm{A}_{\mathrm{A}},}{\mathrm{S}_{\mathrm{A}}^{2}}
\end{gathered}
$$

$\mathrm{S}_{1 \mathrm{~A}}^{2}=$ variance in males of strain $\mathrm{A}$,

$\mathrm{S}_{2 \mathrm{~A}}^{2}=$ variance in females of strain $\mathrm{A}$,

$M_{A}=1 / 2\left(\frac{I}{V 2_{A}}-\frac{I}{V I_{A}}\right)$.

$\sigma_{\Lambda}^{2}=1 / 2\left(\frac{I}{V I_{A}}+\frac{I}{V 2_{A}}\right)$.

$\nu I_{A}==$ d.f. of males of strain $A$,

$\nu \mathbf{I}_{\mathbf{A}}=$ d.f. of females of strain $A$,

and the same for strain $B$. 
Heterosis percentage was calculated as the percentage increase of each of the crossbred groups over the mean of its two parental purebred groups using the following equation.

$$
\mathrm{H} \%=\left[\frac{\text { Ioo } \cdot(\bar{c}-\bar{p})}{\bar{p}}\right]
$$

where :

$$
\begin{array}{ll}
\mathrm{H} \% & =\text { heterosis percent } \\
\bar{c} & =\text { mean of the crossbred group and } \\
\bar{p} & =\text { mean of its } 2 \text { parental purebred groups }
\end{array}
$$

\section{RESULTS}

Mean and variance of male and female body weight for Rhode Island Red $(R I R)$ and Dandarawi (Dand.) strains as well as those of their two reciprocal crosses at different ages studied, are presented in tables $\mathrm{I}, 2,3$ et 4 . The ratios of female to male body weight mean and variance of the same breeding groups at the same ages are also given in the same tables.

\section{TABLE I}

\begin{tabular}{|c|c|c|c|c|c|c|c|c|c|}
\hline \multirow{3}{*}{ Breeding group } & \multicolumn{3}{|c|}{ Mean body weight (gm) } & \multicolumn{6}{|c|}{ Variance in body weight } \\
\hline & \multirow{2}{*}{ Females } & \multirow{2}{*}{ Males } & \multirow{2}{*}{$\begin{array}{c}\text { Female } \\
\text { to male } \\
\text { ratio }\end{array}$} & \multicolumn{2}{|c|}{ Females } & \multicolumn{2}{|c|}{ Males } & \multirow{2}{*}{$\begin{array}{l}\text { Female } \\
\text { to male } \\
\text { ratio }\end{array}$} & \multirow{2}{*}{$\begin{array}{l}\text { Comparison } \\
\text { between female } \\
\text { to male ratios }\end{array}$} \\
\hline & & & & D.F. & $\mathrm{S}^{2}$ & D.F. & $\mathrm{S}^{2}$ & & \\
\hline$=1$ & 218 & 241 & 0.905 & 237 & 1681 & 212 & 1444 & 1.164 & \multirow{4}{*}{$\begin{array}{l}t_{1,2}=0.103 \mathrm{NS} \\
t_{1,3}=0.750 \mathrm{NS} \\
t_{1,4}=0.889 \mathrm{NS} \\
t_{2,3}=0.395 \mathrm{NS} \\
t_{2,4}=0.320 \mathrm{NS} \\
t_{3,4}=0.220 \mathrm{NS}\end{array}$} \\
\hline$R I R-D a n d .\left({ }^{*}\right)=2$ & 213 & 239 & 0.891 & 212 & 2209 & 127 & 2025 & 1.090 & \\
\hline Dand. $-R I R\left(^{*}\right)=3$ & 229 & 254 & 0.901 & 219 & 2209 & 176 & 2209 & 1.000 & \\
\hline Dand. & 178 & 186 & 0.957 & 139 & 1849 & 109 & 1936 & 0.955 & \\
\hline
\end{tabular}

Ratio of female to male body weight mean and variance at 4 weeks of age

Rapport de la valeur moyenne et de la variance du poids corporel des femelles et des mâles à 4 semaines d'âge

$\left.{ }^{*}\right)=$ For crosses, the symbol of strain of sire is listed before that of the dam. The same notation is followed in similar tables.

NS $=$ Non-significant.

Table 5 presents the significance of the group-sex interaction variance for each age.

Heterosis percentages for each cross and sex are given in table 6. 


\section{TABLE 2}

Ratio of female to male body weight mean and variance at 8 weeks of age

Rapport de la valeur moyenne et de la variance du poids corporel des femelles et des mâles à 8 semaines d'âge

\begin{tabular}{|c|c|c|c|c|c|c|c|c|c|}
\hline \multirow{3}{*}{ Breeding group } & \multicolumn{3}{|c|}{ Mean body weight (gm) } & \multicolumn{6}{|c|}{ Variance in body weight } \\
\hline & \multirow{2}{*}{ Females } & \multirow{2}{*}{ Males } & \multirow{2}{*}{$\begin{array}{l}\text { Female } \\
\text { to male } \\
\text { ratio }\end{array}$} & \multicolumn{2}{|c|}{ Fermales } & \multicolumn{2}{|c|}{ Males } & \multirow{2}{*}{$\begin{array}{l}\text { Female } \\
\text { to male } \\
\text { ratio }\end{array}$} & \multirow{2}{*}{$\begin{array}{l}\text { Comparison } \\
\text { between female } \\
\text { to male ratios }\end{array}$} \\
\hline & & & & D.F. & $\mathbf{S}^{\mathbf{2}}$ & D.F. & $\mathbf{S}^{\mathbf{2}}$ & & \\
\hline$=1$ & 488 & 547 & 0.892 & 242 & 7921 & 220 & 8649 & 0.915 & $t_{1,2}=2.4 t_{1} 0 * *$ \\
\hline$R I R$-Dand. $=2$ & 464 & 538 & 0.862 & 225 & 9604 & 127 & 6400 & 1.500 & $\begin{array}{l}t_{1,3}=2.260 \mathrm{NS} \\
t_{1,4}=0.040 \mathrm{NS}\end{array}$ \\
\hline Dand. $-R I R=3$ & 497 & 555 & 0.895 & 198 & 6889 & 171 & 7921 & 0.869 & $\begin{array}{l}t_{2,3}=2.210 * \\
t_{2,4}=1.960 *\end{array}$ \\
\hline Dand. & 359 & 386 & 0.930 & 129 & 6241 & 104 & 6724 & 0.928 & $t_{8,4}=0.297 \mathrm{NS}$ \\
\hline
\end{tabular}

NS $=$ Non-significant.

* = Significant at 0.050 level.

** Significant at 0.025 level.

TABLE 3

Ratio of female to male body weight mean and variance at 12 weeks of age

Rapport de la valeur moyenne et de la variance du poids corporel des femelles et des mâles à 12 semaines d'âge

\begin{tabular}{|c|c|c|c|c|c|c|c|c|c|}
\hline \multirow{3}{*}{ Breeding group } & \multicolumn{3}{|c|}{ Mean body weight (gm) } & \multicolumn{6}{|c|}{ Variance in body weight } \\
\hline & \multirow{2}{*}{ Females } & \multirow{2}{*}{ Males } & \multirow{2}{*}{$\begin{array}{c}\text { Female } \\
\text { to male } \\
\text { ratio }\end{array}$} & \multicolumn{2}{|c|}{ Females } & \multicolumn{2}{|c|}{ Males] } & \multirow{2}{*}{$\begin{array}{l}\text { Female } \\
\text { to male } \\
\text { ratio }\end{array}$} & \multirow{2}{*}{$\begin{array}{c}\text { Comparison } \\
\text { between female } \\
\text { to male ratios }\end{array}$} \\
\hline & & & & D.F. & $\mathrm{S}^{2}$ & D.F. & $\mathbf{S}^{2}$ & & \\
\hline$=-1$ & 872 & 1019 & 0.857 & 225 & 21025 & 210 & 28561 & 0.736 & \multirow{4}{*}{$\begin{array}{l}t_{1,2}=0.709 \mathrm{NS} \\
t_{1,3}=0.476 \mathrm{NS} \\
t_{1,4}=1.560 \mathrm{NS} \\
t_{2,3}=1.010 \mathrm{NS} \\
t_{2,1}=2.092 * \\
t_{3,4}=1.060 \mathrm{NS}\end{array}$} \\
\hline$R I R-D a n d .=2$ & 783 & 945 & 0.829 & 222 & 11236 & 124 & 17689 & 0.635 & \\
\hline Dand. $-R I R=3$ & 862 & 1008 & 0.855 & 187 & 15876 & 160 & 19321 & 0.821 & \\
\hline Dand. & 605 & 666 & 0.908 & 120 & 15129 & 92 & 14161 & 1.068 & \\
\hline
\end{tabular}

* = Significant at 0.050 level. 
TABLE 4

Ratio of female to male body weight mean and variance at 16 weeks of age

Rapport de la valeur moyenne et de la variance du poids corporel des femelles et des mâles à 16 semaines d'âge

\begin{tabular}{|c|c|c|c|c|c|c|c|c|c|}
\hline \multirow{3}{*}{ Breeding group } & \multicolumn{3}{|c|}{ Mean body weight (gm) } & \multicolumn{6}{|c|}{ Variance in body weight } \\
\hline & \multirow{2}{*}{ Females } & \multirow{2}{*}{ Males } & \multirow{2}{*}{$\begin{array}{c}\text { Female } \\
\text { to male } \\
\text { ratio }\end{array}$} & \multicolumn{2}{|c|}{ Females } & \multicolumn{2}{|c|}{ Males } & \multirow{2}{*}{$\begin{array}{c}\text { Female } \\
\text { to male } \\
\text { ratio }\end{array}$} & \multirow{2}{*}{$\begin{array}{c}\text { Comparison } \\
\text { between female } \\
\text { to male ratios }\end{array}$} \\
\hline & & & & D.F. & $\mathrm{S}^{2}$ & D.F. & $\mathrm{S}^{2}$ & & \\
\hline$=1$ & 1249 & 1490 & 0.838 & 201 & 31684 & 180 & 32781 & 0.967 & \multirow{4}{*}{$\begin{array}{l}t_{1,2}=0.970 \mathrm{NS} \\
t_{1,3}=2.145 * \\
t_{1,4}=0.795 \mathrm{NS} \\
t_{2,3}=4.441 * * * \\
t_{2,4}=1.537 \mathrm{NS} \\
t_{9,4}=0.795 \mathrm{NS}\end{array}$} \\
\hline$R I R-$ Dand. $=2$ & 1111 & 1378 & 0.806 & 179 & 30976 & 103 & 25600 & 1.210 & \\
\hline $\operatorname{Dand} .-R I R=3$ & 1184 & 1463 & 0.809 & 171 & 26244 & 135 & 40804 & 0.643 & \\
\hline Dand. & 815 & 950 & 0.858 & 103 & 22500 & 76 & 28561 & 0.787 & \\
\hline
\end{tabular}

* = Significant at 0.050 level.

*** = Significant at 0.001 level.

TABLE 5

Sex $\times$ group interaction

Interaction sexe $\times$ groupe

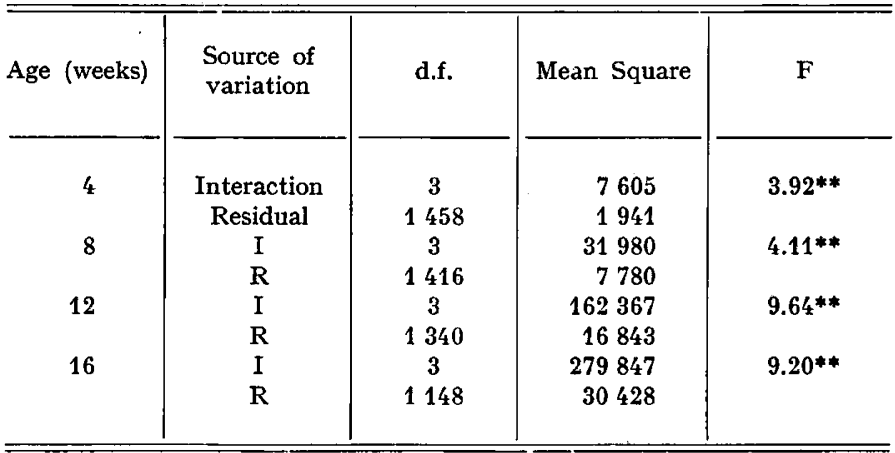


TABLE 6

Heterosis percentages for body weight of Dand.-RIR* and RIR-Dand.* females and males at different ages

Pourcentages d'hétérosis pour le poids corporel de femelles et de mâles Dand-RIR. et RIR-Dand. à différents âges

\begin{tabular}{c|c|c|c|c}
\hline \hline \multirow{2}{*}{$\begin{array}{c}\text { Age in } \\
\text { weeks }\end{array}$} & \multicolumn{2}{|c|}{ Females } & \multicolumn{2}{|c}{ Males } \\
\cline { 2 - 3 } \cline { 4 - 5 } & $\begin{array}{c}\text { Dand.-RIR } \\
(\%)\end{array}$ & $\begin{array}{c}\text { RIR-Dand. } \\
(\%)\end{array}$ & $\begin{array}{c}\text { Dand.-RIR } \\
(\%)\end{array}$ & $\begin{array}{c}\text { RIR-Dand. } \\
(\%)\end{array}$ \\
\hline & & & & \\
\hline 4 & 15.6 & 7.6 & 18.9 & 11.9 \\
8 & 17.3 & 9.1 & 18.9 & 15.5 \\
12 & 16.7 & 5.7 & 19.6 & 12.2 \\
16 & 14.7 & 7.6 & 19.9 & 12.9 \\
20 & 8.4 & 4.9 & 12.9 & 10.2 \\
\hline
\end{tabular}

* = The symbol of strain of sire is listed before that of the dam.

\section{DISCUSSION}

\section{Ratios of female to male body weight mean and variance}

Data in tables $I$ to 4 suggest that the ratio of female to male mean body weight of any of the two reciprocal crosses was of lower value than that of each of the two purebred groups at all ages studied except that of Dand.-RIR crosses at 8 weeks of age when compared with $R I R$ purebred group, since their ratios were nearly the same. Table 5 confirms that the sex $\times$ group interaction is significant at all ages. Generally, these observations also reveal that the difference between the means of the two sexes in each of the crossbred groups of this study (RIR-Dand. and Dand.-RIR groups) was larger than that of any of the purebred groups. This may be due to the existence of homogametic heterosis. In this concern, STonaker (I963) reported that the greater the heterosis in the homogametic sex the greater the sex differences is expected in turkeys and broiler chickens.

As shown in tables $1,2,3$ et 4 , the ratios of female to male body weight variance of the four breeding groups were not in accordance with their corresponding ratios of body weight means. Ratios of female to male body weight variance in the four groups did not differ significantly at four weeks of age (table $r$ ). At eight weeks of age, the two purebred groups showed homogeneity in their ratios of female to male variance, but the crossbred groups differed significantly in this respect (table 2 ), and the $R I R-D a n d$. crossbred group differed significantly from the $R I R$ purebred group $(\mathrm{P}<0.025)$ and from the Dand. group $(\mathrm{P}<0.05)$ at the same age. Significant difference was also observed between the ratio of female to male variance in Dand. group and that in RIR-Dand. crossbred group at twelve weeks of age (table 3 ), as 
well as between the same ratio in $D a n d .-R I R$ crossbred group and that of each of $R I R$ and $R I R-D a n d$. groups at I6 weeks (table 4). Although these results correspond to two by two comparisons, amoy which the probability to obtain at least one significant comparison by chance is higher than in a unique test, it is unlikely that all can be explained in this way, so that they may have some further interpretations. The heterogeneity of the ratio of female to male variance in chicken body weight could not have been caused by natural or artificial eliminations done more in one sex than in the other as can be observed from the numbers of individuals of the two sexes involved in the analysis (tables I, 2, 3 et 4). On the other hand, the average body weight may be expected to have some influence on its variance due to the expected correlation between them. The result obtained in this experiment indicated that there was no relationship between the ratio of variances in the two sexes and either the magnitude of variance or mean of any sex. The differences in the ratio of female to male variance may have specific biological causes. Bearing in mind that the purebred and crossbred groups of this study were brooded and reared under the same conditions, then the following interpretations may be offerred :

I. Different manifestation of genes in both sexes due to different internal environment such as internal physiology and different external environment such as physical activity and social characteristics (EISEN and LEGATES, r966).

2. Different variation between strains (or breeding groups) relative to sexlinked genes.

3. Differences in the degree of homozygosity between strains concerning the sex-linked genes (LERNER, I954).

\section{Heterosis percentage}

Data listed in table 6 reveal that heterotic effects were evident in body weight of female and male chickens of Dand.-RIR and RIR-Dand. crosses at all ages studied, since considerable degrees of heterosis percentages were calculated. This agrees with most reports of the literature.

Heterosis percentage for 4-, 8-, I2-, I6- and 20-week body weight of each of the two crossbred groups were higher for males, the homogametic sex, than those for females, the heterogametic sex (table 6). These observations coupled with findings on the sex difference in chicken body weight, previously discussed in the present report, may confirm the hypothesis of the existence of homogametic heterosis suggested by STONAKER (I962 et I963).

Comparisons of heterosis percentages calculated for crosses resulting from mating Dand. cocks to $R I R$ hens (Dand.-RIR crosses) with those of their reciprocals (RIR-Dand. crosses) illustrate that the amount of heterosis for either the female or male body weight of the former crosses at all ages studied were greater than their correspondings of the latter crosses (table 6). This observation may be due partly to the fact that $R I R$ females are heavier and produce larger eggs and chicks than $D a n d$. females. However this does not seem to be the only explanation, as the difference does not decrease with advancing age.

Results in table 6 indicate that heterosis percentages in body weight of the crossbred female and male chickens increased from 4 to 8 weeks of age then fluctuated 
with advanced age up to 20 weeks when $R I R$ cocks were mated to Dand hens. But, when Dand. cocks were crossed with $R I R$ hens, heterosis percentage in the crossbred female chicken increased from 4 to 8 weeks of age then decreased gradually till 20 weeks of age, and the heterosis percentage for the crossbred males increased with advance in age till 16 weeks and dropped at 20 weeks. These observations indicate that there was no consistent trend for the effect of age on the heterotic effects in body weight of either RIR-Dand. or Dand.-RIR crosses, up to 20 weeks.

Rę̧u pour publication en juin 1976.

\section{RÉSUMÉ}

\section{QUELQUES VARIATIONS HÉRÉDITAIRES DANS DEUX LIGNÉES DE POULETS E'T DANS LEURS CROISEMENTS}

La présente expérience visait à étudier le rapport de la valeur moyenne et de la variance du poids corporel des femelles et des mâles dans des lignées Rhode-Island rouge $(R I R)$ et Dandarawi (Dand.) ainsi que dans leurs deux combinaisons possibles en croisement (RIR-Dand. et Dand.-RIR). Les pourcentages d'hétérosis pour le poids des femelles et des mâles à différents âges jusqu'à 20 semaines ont été aussi calculés. Quatre éclosions successives espacées d'une semaine, comprenant au total I 439 poussins, ont été obtenues. Les conditions d'élevage étaient les mêmes pour les deux lignées et les croisements. Les résultats peuvent être résumés comme suit :

La différence entre le poids corporel moyen des deux sexes dans chacun des croisements réciproques était plus grande que dans les lignées parentales, ce qui indique l'existence probable d'hétérosis homogamétique.

Le rapport de la variance du poids corporel des femelles à celle des mâles n'était pas en accord avec le rapport correspondant des valeurs moyennes. Ce rapport variait suivant le groupe génétique.

Des effets d'hétérosis sur le poids corporel jusqu'à 20 semaines d'âge apparaissaient clairement, mais davantage dans le croisement Dand.-RIR.

Le pourcentage d'hétérosis pour le poids était toujours plus grand pour les mâles (sexe homogamétique) que pour les femelles (sexe hétérogamétique).

Aucune tendance nette n'était décelée quant à l'effet de l'âge des poulets sur les effets d'hétérosis sur le poids du corps jusqu'à 20 semaines.

\section{REFERENCES}

Eisen E. J., Legates J. E., r966. Genotype-sex-interaction and the genetic correlation between the sexes for body weight in Mus Musculus. Genetics, 54, 61 1-623.

Kidwell J. F., 1963. Sex and heterosis in Drosophila melanogaster. Canad. J. Genet. Cytol., 5, 50-56.

Kidwell J. F., NASH D. J., I964. An examination of homogametic heterosis in three species of laboratory animals. Canad. J. Genet. Cytol., 6, 207-214.

Merat P., Ayoub H., 1973. Variation suivant la population du rapport de la variance des mâles à celle des femelles pour le poids corporel chez la Poule. Ann. Génét. Sél. anim., 5, 125-133.

Lerner J. M., r954. Genetic homeostasis. Oliver et Boyd, Edinburgh.

Stonaker H. H., r962. Homogametic heterosis. Proc. Western. Sec. Am. Soc. Animal Prod., 13, 231238.

Stonaker H. H., rg63. A genetic hypothesis for sex-mating system interactions in growth of cattle and poultry. J. Anim. Sci., 22, 320-325. 